\title{
Communication, Teamwork and Stress in Long Term Care Administration
}

\author{
Dr. Ronald M. Fuqua, Ph.D. \\ Assistant Professor of Health Care Management, Clayton State University \\ E-mail: ronaldfuqua@ clayton.edu
}

\author{
Accepted: May 3, 2012 Published: May 31, 2012 \\ Doi:10.5296/jsr.v3i1.1875 \\ URL: http://dx.doi.org/10.5296/jsr.v3i1.1875
}

\begin{abstract}
The goals of this study were to identify how long term care administrative employees felt about communication, teamwork and stress in doing their work. Data from long term care administrative employees on their comparative opinions of receiving information and being asked for their input, giving help to others and receiving help in doing their jobs, and their opinions of the stress level in their jobs were collected through an online survey. Analysis provides an assessment of associations between demographic information and administrative employees' opinions. Results include statistically significant associations, using Pearson correlations. The differences between being told what they needed to know and being asked for their input, as well as the opinions about giving as opposed to receiving help from others and the level of stress in their jobs were found meaningful. Implications from these data include value and contribution in implementing health care management curriculum delivery based upon long term care administrative employees' perceptions.
\end{abstract}

Keywords: Communication, Teamwork, Stress, Long Term Care

\section{Introduction}

Long term care is a growing field in health care delivery. As such, it is unique among health care providers in the increasing risk for staff and management stress related burnout. When workers and leaders in long term care are asked about their work, it is common to hear that better communication, more teamwork and less stress would make the work environment better. This paper reports on the opinions of long term care workers who have administrative responsibilities and how they feel about two major elements of communication, two perspectives on teamwork, and stress in their jobs. Communication includes sending and receiving messages while teamwork typically includes helping others and being helped by others. 


\section{Purpose}

The purpose of this study was to identify how long term care workers in administrative positions felt about whether they are told what they need to know and whether they are asked for their input about their work. Additionally, these administrative workers were asked how often they received help as well as how often they helped others in doing the work of long term care. Finally, the perception of these health care workers regarding excessive stress in their jobs was analyzed. Responses were received from 107 of 165 survey invitations for a response rate of $65 \%$, provided data to assess these opinions.

\section{Review of the Literature}

Stefl (2008) reported that today's health care executives and leaders must have talent sophisticated enough to match the increased complexity of the health care environment. She reports the number one competency is communication and relationship management. Garman, et al, (2006) state that the competency of communication and relationship management leverages professionalism and allows health care leaders to develop, cultivate and maintain effective working relationships.

Teamwork is addressed by Firth-Cozens when she describes organizations as a dynamic balance between the authority and autonomy of the individual, the control that exists in formal structures, and the cooperation that takes place within and between teams. Erikson, et al, (2006) studied the psychological distress among nurses' aides and stated that nurses' aides, the main providers of practical patient care in many countries, are doing both emotional and heavy physical work, and are exposed to frequent social encounters in their job.

So why should communication, teamwork and stress among administrative workers in long term care be researched? According to Shirey (2006), implementation of authentic leadership can affect not only the nursing workforce and the profession but the healthcare delivery system and society as a whole. Creating a healthy work environment for nursing practice is crucial to maintain an adequate nursing workforce; the stressful nature of the profession often leads to burnout, disability, and high absenteeism and ultimately contributes to the escalating shortage of nurses. Leaders play a pivotal role in retention of nurses by shaping the healthcare practice environment to produce quality outcomes for staff nurses and patients. Few guidelines are available, however, for creating and sustaining the critical elements of a healthy work environment. It is for this reason that this research was initiated.

\section{Design}

In this research, an online survey, Figure 1-3, using a commercially available software application to deliver an instrument developed to measure opinion on a 4-point Likert-type 
scale, was made available to all administrative employees in 52 skilled nursing centers. Participation was anonymous and voluntary. The survey was designed to access employees' perception, or feeling, of how often they were told what they needed to know in their jobs and how often their input was solicited about the job. With regard to teamwork, the opinion of these employees was sought concerning how often they helped others and how often they were helped by others. Finally, the perceived frequency of excessive stress was obtained from the respondents. The response rate for the survey was 65\% with 107 of 165 administrative employees participating in the survey.

\section{Findings}

Analysis showed that the majority of long term care administrative employees surveyed $(\mathrm{N}=107,65 \%$ response rate) had more than 10 years of employment service, had some college education, were female, and were non-minority. More than 49 percent of them said they were asked some for their input on the job and only $8 \%$ said it was never or not enough. Over $71 \%$ said they were often told what they needed to know to do their work while just over $3 \%$ said they were not told what they needed to know. Almost $89 \%$ of the respondents said they very often helped others do their jobs while only $38 \%$ said they were very often helped by others in doing their jobs. More than 68\% of those responding said they somewhat often or very often experienced excessive stress in their jobs.

\section{Correlations}

The results of this research present statistically significant associations. Table 10 contains seven statistically significant findings, at the $\mathrm{P}=0.01$ level of significance, in descending order, of their magnitude of association. These include positive associations between feelings of long term care administrative workers being told what they need to know in doing their jobs with being asked for their input on doing their job with a correlation coefficient of 0.65 . The next strongest relationship indicated that workers who were helped by others in doing their jobs were asked for their input with a correlation coefficient of 0.44 .

Another positive association existed between administrative workers who were helped by others in doing their jobs and being told what they needed to know in order to do their work. The final positive and statistically significant association was between those who were asked for their input and the length of service where the association was 0.22 .

Interestingly, the factors that had the most association on feeling less excessive stress in the job were being helped by others in doing the job, being told what was needed to do the job and being asked for input in doing the job.

\section{Practical Applications}

Administering long term care is demanding work. Patients are much more dependent in the 
long term care setting than in other health care delivery areas while staff demands are high. This research indicates that social factors have an association to how well administrative workers are able to perform their jobs. The interrelatedness of being helped by others in a teamwork fashion that benefits the one receiving help, along with both aspects of communication, sending messages to others and receiving information needed to do the job, contribute to a lower perception of excessive stress in the work. There is also the idea that when these positive things happen, better teamwork that is seen as receiving help, and better two-way communication, the length of service in the field of long term care is lengthened.

\section{Administration in Long Term Care:}

Health care administrators in long term care are constantly facing challenges of better communications, more teamwork and managing stress reduction for themselves and their staff. Developing a program of positive, two-way communication is important in the pursuit of a teamwork oriented staff. The more who feel they are asked for their input in doing their jobs and are told what they need to know in doing their jobs, the more likely staff members will be inclined to help others in doing their jobs as well as receive help from others. When these qualities of work are realized, stress is felt as less excessive.

\section{Originality/Value \& Contribution}

Long term care administrators are responsible for the quality of health care their teams deliver to their patients. It has long been understood that the more satisfied the long term care workforce, the higher quality of care that is delivered to the patients. It is also widely recognized that some of the most commonly cited reasons for lower employee satisfaction are poor communication, low levels of teamwork and high levels of stress. This research supports the ideas that better communication, both in sending and receiving information, as well as higher levels of teamwork contribute to a reduced level of stress, at least in what was seen as excessive stress. In order to achieve these desired results, health care management programs of education should emphasize effective communications, team building and stress reduction and management.

\section{Tables}

\begin{tabular}{|l|l|l|}
\hline Table 1 - Employment Service & & \\
\hline Less than 1 year & 11 & $10.28 \%$ \\
\hline 1-2 years & 10 & $9.35 \%$ \\
\hline 3-5 years & 12 & $11.21 \%$ \\
\hline 5-10 years & 14 & $13.08 \%$ \\
\hline More than 10 years & 60 & $\mathbf{5 6 . 0 7 \%}$ \\
\hline Grand Total & 107 & \\
\hline
\end{tabular}

Table 2 - Education 


\begin{tabular}{|l|l|l|}
$\begin{array}{l}\text { High school degree or } \\
\text { equivalent (e.g., GED) }\end{array}$ & 27 & $25.23 \%$ \\
\hline Some college but no degree & 41 & $38.32 \%$ \\
\hline Associate degree & 8 & $7.48 \%$ \\
\hline Bachelor degree & 21 & $19.63 \%$ \\
\hline Graduate degree & 10 & $9.35 \%$ \\
\hline Grand Total & 107 & \\
\hline
\end{tabular}

\begin{tabular}{|l|l|l|}
\hline Table 3 - Gender & & \\
\hline Female & 94 & $87.85 \%$ \\
\hline Male & 13 & $12.15 \%$ \\
\hline Grand Total & 107 & \\
\hline
\end{tabular}

\begin{tabular}{|l|l|l|}
\hline Table 4 - Minority & & \\
\hline Asian & 3 & $2.80 \%$ \\
\hline Black & 16 & $14.95 \%$ \\
\hline Other & 2 & $1.87 \%$ \\
\hline White & 86 & $80.37 \%$ \\
\hline Grand & 107 & \\
\hline
\end{tabular}

\begin{tabular}{|l|l|l|}
\hline Table 5-Asked For Their Input & & \\
\hline Never & 5 & $4.81 \%$ \\
\hline Not enough & 3 & $2.88 \%$ \\
\hline Some & 51 & $49.04 \%$ \\
\hline Often & 45 & $43.27 \%$ \\
\hline Grand & 104 & \\
\hline
\end{tabular}

\begin{tabular}{|l|l|l|}
\hline $\begin{array}{l}\text { Table 6 - Told What They Needed } \\
\text { to Know }\end{array}$ & & \\
\hline Never & 2 & $1.89 \%$ \\
\hline Not enough & 2 & $1.89 \%$ \\
\hline Often & 76 & $71.70 \%$ \\
\hline Some & 26 & $\mathbf{2 4 . 5 3 \%}$ \\
\hline Grand Total & 106 & \\
\hline
\end{tabular}




\begin{tabular}{|l|l|l|}
\hline Table 7 - Helped Others & & \\
\hline Not very often & 1 & $\mathbf{0 . 9 5 \%}$ \\
\hline Somewhat often & 11 & $10.48 \%$ \\
\hline Very often & 93 & $\mathbf{8 8 . 5 7 \%}$ \\
\hline Grand Total & 105 & \\
\hline
\end{tabular}

\begin{tabular}{|l|l|l|}
\hline Table 8 - Helped By Others & & \\
\hline Never & 1 & $0.94 \%$ \\
\hline Not very often & 14 & $13.21 \%$ \\
\hline Somewhat often & 40 & $37.74 \%$ \\
\hline Very often & 51 & $48.11 \%$ \\
\hline Grand Total & 106 & \\
\hline
\end{tabular}

\begin{tabular}{|l|l|l|}
\hline $\begin{array}{l}\text { Table 9 - Felt Excessive Stress In } \\
\text { Their Jobs }\end{array}$ & & \\
\hline Never & 3 & $\mathbf{2 . 8 0 \%}$ \\
\hline Not very often & $\mathbf{3 1}$ & $\mathbf{2 8 . 9 7 \%}$ \\
\hline Somewhat often & $\mathbf{4 0}$ & $\mathbf{3 7 . 3 8 \%}$ \\
\hline Very often & $\mathbf{3 3}$ & $\mathbf{3 0 . 8 4 \%}$ \\
\hline Grand Total & $\mathbf{1 0 7}$ & \\
\hline
\end{tabular}

\begin{tabular}{|l|l|}
\hline $\begin{array}{l}\text { Table 10 - Correlated (P=.01) } \\
\text { Variables and Coefficients }\end{array}$ & Pearson \\
\hline $\begin{array}{l}\text { Told what they needed to know with } \\
\text { Asked for input }\end{array}$ & $\mathbf{0 . 6 4 8 0 9 5}$ \\
\hline $\begin{array}{l}\text { Helped with their job with } \underline{\text { Asked }} \\
\text { for input }\end{array}$ & $\mathbf{0 . 4 4 4 0 2 6}$ \\
\hline $\begin{array}{l}\text { Helped with their job with } \text { Told } \\
\text { what they needed to know }\end{array}$ & $\mathbf{0 . 2 6 9 6 0 5}$ \\
\hline $\begin{array}{l}\text { Asked for their input with Service } \\
\text { of employment }\end{array}$ & $\mathbf{0 . 2 2 1 4 6 6}$ \\
\hline$\underline{\text { Stress with Helped with their job }}$ & $\mathbf{- 0 . 1 2 7 4}$ \\
\hline$\underline{\text { Stress with } \underline{\text { Told } \text { what they needed }}}$ & \\
to know & $\mathbf{- . 0 1 0 4 4 9}$ \\
\hline Stress with $\underline{\text { Asked for input }}$ & $\mathbf{- . 0 6 3 4 7}$ \\
\hline
\end{tabular}

Figure 1 - Survey Page 1 


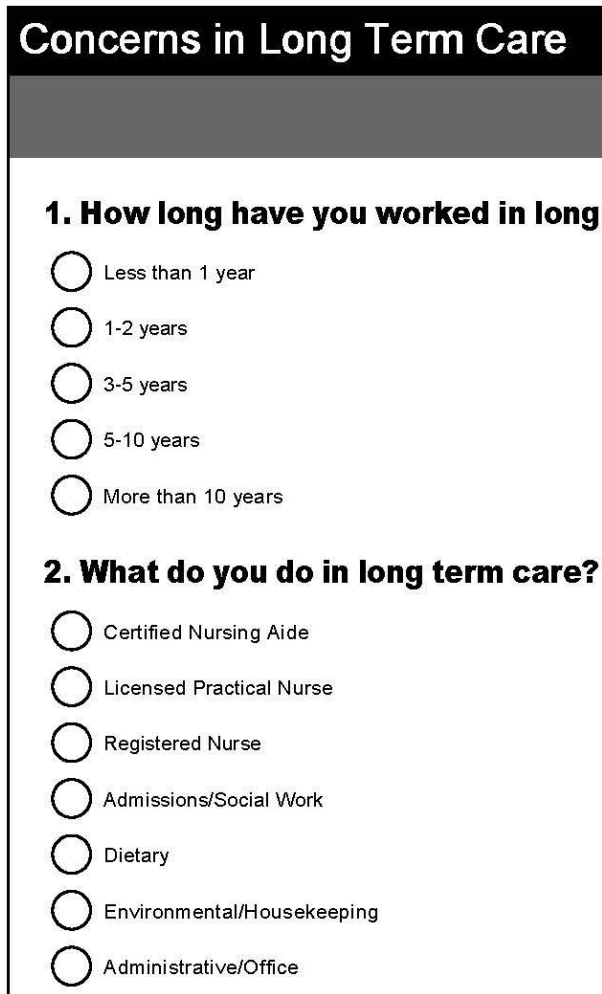

3. What is the highest level of school you have completed or the highest degree you have received?

Less than high school degree

High school degree or equivalent (e.g., GED)

some college but no degree

$\bigcirc$ Associate degree

Bachelor degree

Graduate degree

\section{What is your gender?}
Female
$\bigcirc$ Male

Figure 2 - Survey Page 2 


\begin{tabular}{|r} 
Macrothink \\
Institute
\end{tabular}

\section{Concerns in Long Term Care}

5. What is your minority status?
Black
Hispanic
$\bigcirc_{\text {Asian }}$
$\bigcirc$ white
other

6. How often are you asked your opinion by your leadership?
often
some
Not enough
Never

7. How often are you told what you need to know by your leadership?
often
some
Not enough
Never

8. How often in your job do you help others?
very often
somewhat often
Not very often
Never

9. How often in your job do others help you?
$\bigcirc$ very often
$\bigcirc$ somewhat often
$\bigcirc$ Not very often
Never

Figure 3 - Survey Page 3 
Concerns in Long Term Care

10. How often do you feel excessive stress in the work you do?

$\bigcirc$ very often

Somewhat often

$\bigcirc$ Not very often

Never 


\section{References}

Batalden, P., Leach, D., Swing, S., Dreyfus, H. \& Dreyfus, S. (2002). General competencies and education in graduate medical education. Health Affairs. 21 (5), 103-111.

Bradley, E. (2003). Use of evidence in implementing competency-based healthcare management training. Journal of Health Administration Education. 20 (4), 287-304.

Erikson, W., Tambs, K., Knardahl, S. (2006). Work factors and psychological distress in nurses' aides: a prospective cohort study. BMC Public Health. 6 (290).

Firth-Cozens, J. (2001). Cultures for improving patient safety through learning: the role of teamwork. Quality in Healthcare. 10 (Suppl II) ii26-ii31.

Garman, A., Fritz, K., \& Fraser, M. (2006). Communication and relationship management. Journal of Healthcare Management. 51 (5), 201-294.

Shirey, M. (2006). Authentic leaders creating healthy work environments for nursing practice. Journal of Critical Care. 15 (3), 256-267.

Stefl, M. (2008). Common competencies for all healthcare managers: The Healthcare Leadership Alliance model. Journal of Healthcare Management. November-December, 360-373. 